\title{
Sclera-Specific and Non-Sclera-Specific Autoantibodies in the Serum of Patients with Non-Infectious Anterior Scleritis
}

\section{Auto-anticorpos contra Antígenos Específicos e Não-específicos da Esclera no Soro de Pacientes com Esclerite Anterior Não-infecciosa}

\author{
Wagner Koji Aragaki(1) ${ }^{(1)}$ Luciene Barbosa de Sousa ${ }^{(1)}$, Virgínia Fernandes Moça Trevisani ${ }^{(2)}$, \\ Hellen Fuzzi ${ }^{(3)}$, Luís Eduardo Coelho Andrade ${ }^{(2)}$
}

\begin{abstract}
Objectives: to study the frequency and specificity of scleraspecific and non-sclera-specific autoantibodies in the sera of patients with anterior non-infectious scleritis. Methods: prospective study involving 25 patients examined at the sector of Cornea and External Disease of the Department of Ophthalmology and Immuno-Rheumatology Laboratory at Federal University of São Paulo/Paulista Medicine School, during one year. The diagnosis of scleritis was according to Watson and Hayreh 's (1976) classification criteria. The exclusion criterion was infectious scleritis. All the patients underwent a full clinical and ophthalmologic evaluation, including serological tests for syphilis and tuberculosis investigation. The following autoantibodies were tested: rheumatoid factor, antinuclear antibodies, anticardiolipin antibodies, ANCA (anti-neutrophil cytoplasmic antibodies), anti-SS-A/Ro, anti-SS-B/La, anti-Sm, anti-DNA and anti-APF (antiperinuclear factor). For sclera-specific autoantibodies, sera of all patients were subjected to indirect immunofluorescence and Western blot assays, using human sclera from eye banks as a substrate. Sera from 25 healthy individuals were used as a normal control in the immunologic assays. Results: as nonsclera-specific autoantibodies we detected one patient with positive rheumatoid factor, two patients with positive antinuclear antibodies, two patients with positive anticardiolipin antibody and two patients with positive anti-APF. Scleraspecific autoantibodies were detected by Western blot and immunofluorescence in the serum of two patients with scleritis. The two patients with sclera-specific autoantibodies did not show non-sclera-specific autoantibodies and also presented no evidence of autoimmune rheumatic disease. Normal controls
\end{abstract}

\section{RESUMO}

Objetivos: estudar a freqüência e especificidade de auto-anticorpos contra antígenos específicos e não específicos da esclera no soro de pacientes com esclerite anterior não infecciosa. Métodos: foi realizado estudo prospectivo envolvendo 25 pacientes examinados no Setor de Córnea e Doenças Externas do Departamento de Oftalmologia da Unifesp-EPM e no Laboratório de Imuno-Reumatologia da UnifespEPM, durante um ano. Os critérios de esclerite foram estabelecidos conforme a classificação de Watson e Hayreh (1976). Os critérios de exclusão foram as esclerites infecciosas. Todos os pacientes tiveram avaliações clínica e oftalmológica completas, incluindo exames laboratoriais para afastar doenças infecciosas como a sífilis e a tuberculose. Os seguintes auto-anticorpos foram testados: fator reumatóide, anticorpos antinucleares, anticorpos anticardiolipina, ANCA (anticorpos anticitoplasmáticos de neutrófilos), anti-SS-A/Ro, anti-SS-B/La, anti-Sm, anti-DNA e anti-APF (anticorpos antifator perinuclear). Para a pesquisa de auto-anticorpos contra antígenos específicos da esclera, o soro dos pacientes foi submetido à técnica de imunofluorescência indireta e Western-blot utilizando esclera humana obtida em banco de olhos, como substrato. Os soros de 25 pacientes hígidos foram utilizados como grupo controle nos testes imunológicos. Resultados: auto-anticorpos contra antígenos não específicos da esclera foram detectados: um paciente com fator reumatóide positivo, dois pacientes com fator antinúcleo positivos, dois pacientes com anticorpos anticardiolipina positivos e dois pacientes com anti-APF. Auto-anticorpos contra antígenos específicos da esclera pela técnica de imunofluorescência indireta e Western-blot foram detectados no soro de dois pacientes com esclerite. Os dois pacientes com autoanticorpos contra antígenos específicos da esclera não apresentavam auto-anticorpos contra antígenos não específicos da esclera nem tinham doença reumática auto-imune. Os controles normais foram

Recebido em 06/03/07. Aprovado, após revisão, em 05/05/07.

1. Doutor em Ciências pela Universidade Federal de São Paulo (Unifesp). Departamento de Oftalmologia

1. Doutora em Ciências pela Unifesp. Departamento de Oftalmologia.

2. Doutora em Ciências pela Unifesp. Disciplina de Reumatologia

3. Doutora em Ciências pela Unifesp. Universidade Federal de São Paulo, São Paulo - Brasil, Universidade Federal do Pará, Belém

2. Livre-docente da Disciplina de Reumatologia na Unifesp.

Agradecimentos: Dr. Carlos Eduardo Pavésio- Moorfields Eye Hospital -UK

Endereço para correspondência: Dr. Wagner Koji Aragaki, Rua Ascencional, 172, ap. 81, Jardim Ampliação, CEP 05713-430, São Paulo, SP, Brasil, e-mail: wka@uol.com.br 
were negative for all tested autoantibodies. Conclusions: Sclera-specific autoantibodies were detected solely in the serum of patients with isolated non-infectious anterior scleritis. Non-sclera-specific autoantibodies were observed in patients with scleritis associated with autoimmune rheumatic disease and in patients with isolated scleritis.

Keywords: autoantibodies, scleritis, autoimmunity, autoantigens.

\section{BACKGROUND}

Scleritis is an inflammatory disorder that may present as an isolated ophthalmic condition or as a manifestation of systemic conditions such as rheumatoid arthritis, systemic lupus erythematosus, vasculitis, and other autoimmune diseases $^{(1-2)}$. The exact pathophysiology of scleritis, however, has not been yet totally elucidated. The etiologic diagnosis of scleritis remains a challenge in the clinical practice and is frequently not established. The abscence of a definite etiologic diagnosis often evokes the possibility of an autoimmune etiology and an immunosuppressive treatment is frequently empirically initiated. Although much research has been devoted to the relationship between scleritis and autoimmunity, the issue is far from being clarified ${ }^{(3)}$.

The detection of auto-antibodies and inflammatory mediators in the serum of patients with scleritis has been taken as evidence of the participation of the immune system. Antiphospholipid antibodies and increased serum levels of tumor necrosis factor (TNF) have been demonstrated in some patients with scleritis ${ }^{(4-6)}$. Antibodies against $54 \mathrm{kDa}$ and $70 \mathrm{kDa}$ epithelial proteins in sera of patients with corneal involvement in the context of rheumatoid arthritis and Wegener's granulomatosis, respectively, have been identified ${ }^{(7)}$. Similarly, patients with Mooren's ulcer have been shown to carry serum antibodies against a protein called calgranulin ( $7 \mathrm{kDa}$ ) which is able to induce experimental autoimmune keratitis ${ }^{(8-9)}$.

Autoantigens with high probability of representing an immune stimulus capable of inducing scleritis should reside within the proteoglycan matrix ${ }^{(10)}$. Putative changes in the proteoglycan lattice would expose novel epitopes during an ongoing non-specific inflammatory process, which would ultimately drive an autoimmune response. However, no specific autoantigen or autoantibody has been identified so far in the context of immune mediated scleritis $^{(11)}$. negativos para todos os auto-anticorpos testados. Conclusões: Autoanticorpos contra antígenos específicos da esclera foram detectados única e isoladamente no soro de pacientes com esclerite anterior não infecciosa. A presença de auto-anticorpos contra antígenos não específicos da esclera foi observada em pacientes com doença reumática auto-imune e em pacientes com esclerite isolada.

Palavras-chave: auto-anticorpos, esclerites, auto-imunidade, auto-antígenos.

\section{OBJECTIVES}

To study the frequency and specificity of sclera-specific and non-sclera-specific autoantibodies in the serum of patients with anterior non-infectious scleritis.

\section{PATIENTS AND METHODS}

During a period of one year 25 patients over 18 years of age diagnosed as having anterior non-infectious acute scleritis were consecutively selected from the External Eye and Corneal Diseases Outpatient Clinic at the Ophthalmology Department at Federal University of São Paulo - Brazil. All the patients signed a Consent Form approved by the Institution Ethics Committee. Patients underwent clinical, rheumatologic and ophthalmologic screening according to a specific protocol. Serological tests for syphilis (VDRL and FTA-ABS) and tuberculosis (TST-tuberculin skin test) were also done to exclude infectious scleritis. Scleritis was classified according to the criteria proposed by Watson et al. ${ }^{(11)}$ into diffuse, nodular and necrotizing anterior scleritis. Peripheral ulcerative keratitis (PUK) was defined as the presence of corneal thinning with ulceration of surrounding cornea. Uveitis was diagnosed by the presence of one of the following: inflammatory cells in the anterior chamber, iris synechiae, endothelial keratic precipitates or fundoscopic changes $^{(12,13)}$.

Serum from patients was tested for antinuclear antibodies ( $A N A$ ) by indirect immunofluorescence technique (IIF) on HEp-2 cells (Hemagen, Whalton, MD)(14), rheumatoid factor $(R F)$ by latex particle agglutination technique ${ }^{(15)}$, anticardiolipin antibodies (IgM and $\operatorname{IgG}$ ) by solid phase immunoenzymatic technique(16), anti-native DNA antibodies by IIF on Crithidia Iucilae(17), anti-Sm, anti-RNP, anti-SS-A/Ro and anti-SS-B/La antibodies by double immunodifusion technique against calf spleen extract ${ }^{(18)}$, anti-neutrophil cytoplasm antibodies (c-ANCA and $p$-ANCA) by $I I F^{(19)}$ and antiperinuclear factor (APF) according to the Hoet method(20). 
Sclera-specific autoantibodies were determined by indirect immunofluorescence and western blot using human sclera as substrate. For the indirect immunofluorescence assay, $4 \mu \mathrm{m}$-thick sclera cryosections mounted over regular glass slides were fixed with acetone at $-20^{\circ} \mathrm{C}$ for $10 \mathrm{minu}$ tes. After incubation with patient's serum diluted 1:20 in phosphate buffered saline pH 7.2 (PBS) for 30 minutes at $37^{\circ} \mathrm{C}$, slides were thoroughly washed in $P B S$ and incubated with fluorescein-labeled goat anti-human IgG (Fluolab, São Paulo, Brazil) for 25 minutes at room temperature. After washing for removal of buffer excess, slides were mounted with buffered glycerin and cover slips. Serum samples from 25 healthy controls were tested in parallel. Slides were analyzed under an $\mathrm{Hg}$-powered fluorescence microscope (Olympus ${ }^{\circledR}$ BX 50) at $\times 400$ magnification and photmacrographs were obtained with an Olympus ${ }^{\circledast}$ PM-30 camera. All analyses were carried out by two independent blinded investigators.

For the Western blot assays fragments of sclera frozen at $-120^{\circ} \mathrm{C}$ were grinded, resuspended into $1 \mathrm{~mL} P B S$ with and protease inhibitors (aprotinin $10 \mathrm{mg} / \mathrm{mL}$, leupeptin $10 \mathrm{mg} / \mathrm{mL}$, EDTA $0.5 \mathrm{M}$ and PMSF $10 \mathrm{mg} / \mathrm{mL}$ ), and sonicated at grade 3 in a Branson ${ }^{\circledR}$ sonicator for 5 minutes. Samples were then homogenized by means of 10 strokes in a Douncer-type homogenizer. The homogenate was mixed volume to volume with $2 x$ Laemmli buffer (SDS $4,6 \mathrm{~g}$, 2-mercaptoethanol $10 \mathrm{~mL}$, glycerol $20 \mathrm{~mL}$, bromophenol blue $0.1 \% 2 \mathrm{~mL}$, tris-HCL 12,5 $\mathrm{mL}$, distilled water) and $1 \mathrm{~mL}$ guanidine $0,4 \mathrm{M}$ buffer. The sclera extract was kept under constant agitation at $4^{\circ} \mathrm{C}$ for a 12-hour period then kept at $-80^{\circ} \mathrm{C}$. Immediately before western blot the sclera extract was heated to $100^{\circ} \mathrm{C}$ for about 5 minutes and centrifuged for 10 minutes at $10,000 \mathrm{~g}$. The supernatant was subjected to electrophoresis in 12.5\% SDS-polyacrilamide gel. After transferring to nitrocellulose, $0.5 \mathrm{~cm}$-wide vertical strips were cut and soaked into blocking buffer (1\% BSA 0.05\% Tween 20 PBS) for 2 hours at room temperature. Serum aliquots to be tested were diluted 1:20 into blocking buffer and incubated with individual nitrocellulose strips for 1 hour, under agitation, at room temperature. The nitrocellulose strips were then washed with washing buffer (0.05\% Tween PBS) for 15 minutes three times under agitation, and incubated with goat anti-human gamaglobulin antibody conjugate to protein $A$ (Amerchan-Bioscience $^{\circledR}$ ) diluted $1 / 1000$ in blocking buffer for 30 minutes at room temperature. After washing as before, strips were incubated with carbonate-bicarbonate buffer $\mathrm{pH} 9.0$ for 5 minutes. After removing buffer excess nitrocellulose strips were placed between two acetate sheets and luminol (ECL 750 I-Amerchan-Bioscience ${ }^{\circledR}$ ) was placed over them to form a fluid film. After I minute, the assembly was put into a light-proof cassette and exposed to radiographic film Kodak ${ }^{\circledR}$ (Kodak.S.P, Brazil) for 30 to 50 seconds. The films were developed and fixed manually. Reading of the films was performed by two independent blinded observers.

The positive control for the Western blot and IIF assays was monoclonal antibody against the extracellular protein laminine (Seikagaku ${ }^{\circledR}$ - Japan) diluted 1:4000. This monoclonal antibody was expected to produce a band with an estimated molecular weight near 50kDa. In IIF, the monoclonal antibody yielded a high intensity staining with a peculiar lamellar pattern. As mentioned before, serum samples from 25 healthy volunteers were used as negative controls.

\section{RESULTS}

Fifteen patients (60\%) were over 51 years old, and ten patients (40\%) were in the range between 20 and 50 years old. Twenty-two patients (88\%) were female. Nineteen patients (76\%) had unilateral and six patients (24\%) bilateral scleritis. Thirteen patients (52\%) had anterior nodular, 11 patients (44\%) had anterior diffuse, and one patient (4\%) had anterior necrotizing scleritis. Seven patients (28\%) had peripheral ulcerative keratitis, and two patients (8\%) had anterior uveitis. Twenty-two patients (88\%) did not have previous eye dysfunction, one patient (4\%) underwent previous cataract surgery, one patient (4\%) underwent previous pterygium surgery, and one patient (4\%) had dry eye diagnosis. Twenty-two patients (88\%) had no apparent systemic involvement, while two patients (8\%) had systemic lupus erythematosus, and one patient (4\%) had rheumatoid arthritis (RA).

The frequency of non-sclera-specific antibodies was low in the study group: one patient (4\%) presented rheumatoid factor at a 1:160 titer, two patients (8\%) presented a positive ANA test with nuclear fine speckled pattern at 1:320 and 1:80 titers, respectively, two patients (8\%) presented low titer anticardiolipin antibodies (11 GPL and 12 GPL, respectively) and two patients (8\%) presented a positive antiperinuclear factor test at 1:320 and 1:80 titers, respectively.

Clinical and immunological characteristics of non-scleraspecific antibodies are showed in table $I$. 
TABLE I

FEATURES OF POSITIVE NON-SCLERA-SPECIFIC AUTOANTIBODIES

\begin{tabular}{lcccc}
\hline $\begin{array}{l}\text { Positive } \\
\text { non-sclera- } \\
\text { specific } \\
\text { autoantibodies }\end{array}$ & $\begin{array}{c}\text { Auto- } \\
\text { antibodies }\end{array}$ & $\begin{array}{c}\text { Other } \\
\text { ocular } \\
\text { disorders }\end{array}$ & Scleritis & $\begin{array}{c}\text { Systemic } \\
\text { disorders }\end{array}$ \\
\hline Patient 3 & ANA and APF & - & $\begin{array}{c}\text { Anterior } \\
\text { nodular }\end{array}$ & - \\
Patient 4 & RF & - & $\begin{array}{c}\text { Anterior } \\
\text { nodular }\end{array}$ & - \\
Patient 6 & Anticardiolipin & - & $\begin{array}{c}\text { Anterior } \\
\text { nodular }\end{array}$ & - \\
Patient 12 & Anticardiolipin & $\begin{array}{c}\text { Peripheral } \\
\text { ulcerative } \\
\text { keratitis }\end{array}$ & $\begin{array}{c}\text { Anterior } \\
\text { difuse }\end{array}$ & - \\
\hline Patient 15 & APF & - & $\begin{array}{c}\text { Anterior } \\
\text { difuse }\end{array}$ & - \\
Patient 22 & ANA & - & $\begin{array}{c}\text { Anterior } \\
\text { difuse }\end{array}$ & $\begin{array}{c}\text { Systemic } \\
\text { Lupus }\end{array}$ \\
\hline
\end{tabular}

Sclera-specific autoantibodies were also detected in low frequency. The serum of two patients presented a strong homogeneous lamellar staining pattern that was reproducible in repeated assays (Figure 1). The serum of these same patients recognized two bands with an estimated relative mobility of $40 \mathrm{kDa}$ and $15 \mathrm{kDa}$, respectively (Figure 2). None of the other scleritis patients and healthy volunteers presented a relevant reactivity on IIF and Western blot.

Clinical and immunological characteristics of scleraspecific autoantibodies are showed in Table II.

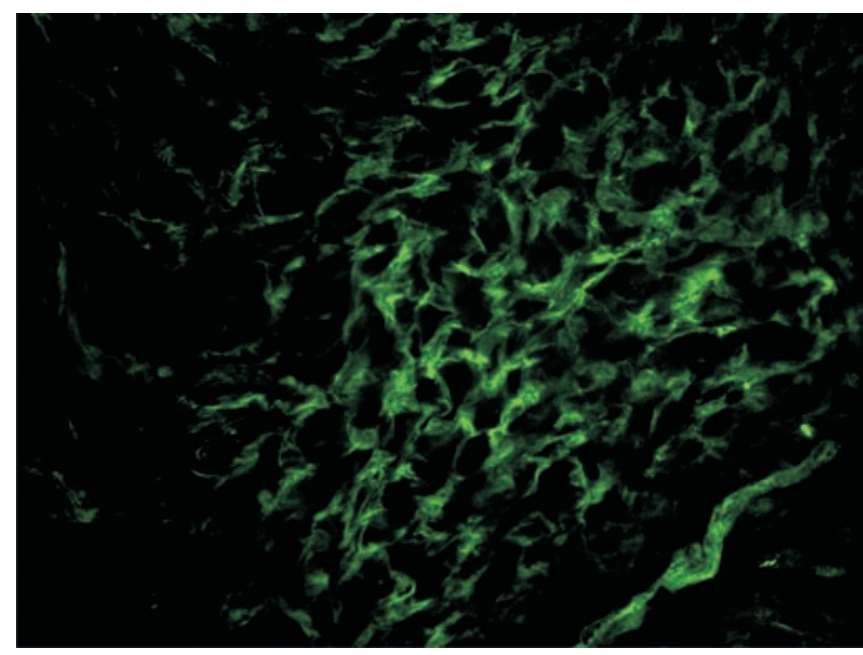

Figure 1 - Indirect immunofluorescence in scleral tissue by using serum of patient 1 : extra cellular matrix is stained in a homogeneous pattern. Magnification of $\times 400$.
TABLE II

FEATURES OF POSITIVE SCLERA-SPECIFIC AUTOANTIBODIES IN PATIENTS 1 AND 2

\begin{tabular}{lcccc}
\hline $\begin{array}{l}\text { Positive } \\
\text { sclera-specific } \\
\text { autoantibo- } \\
\text { dies }\end{array}$ & $\begin{array}{c}\text { 0ther } \\
\text { ocular } \\
\text { disorders }\end{array}$ & Scleritis & $\begin{array}{c}\text { Systemic } \\
\text { disorders }\end{array}$ & $\begin{array}{c}\text { Non-sclera- } \\
\text { specific } \\
\text { antibodies }\end{array}$ \\
\hline Patient 1 & $\begin{array}{c}\text { Peripheral } \\
\text { ulcerative } \\
\text { keratitis and } \\
\text { uveitis }\end{array}$ & $\begin{array}{c}\text { Anterior } \\
\text { diffuse }\end{array}$ & - & Negative \\
Patient 2 & - & $\begin{array}{c}\text { Anterior } \\
\text { diffuse }\end{array}$ & - & Negative \\
\hline
\end{tabular}

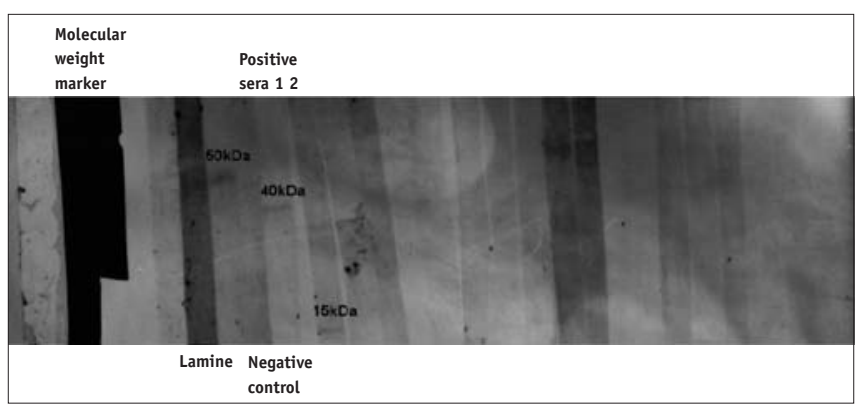

Figure 2 - Western blot using sclera whole extract as substrate: Molecular weight marker (GE Healthcare Bio-sciences ${ }^{\circledR}$ ), monoclonal antibody against laminine (Seikagaku ${ }^{\circledR}$ - Japan) with $50 \mathrm{kDa}$ band (positive control) and negative control (no bands visible). Reactivity against a $15 \mathrm{kDa}$ and a $45 \mathrm{kDa}$ band was observed with only two sera from patients with scleritis (patients 1 and 2).

\section{DISCUSSION}

The present study reports for the first time the presence of sclera-specific autoantibodies in the serum of patients with non-infectious scleritis. These were observed in low frequency in the present sample. A low frequency of non-sclera-specific autoantibodies was also demonstrated. Patients with sclera-specific autoantibodies did not present non-sclera-specific autoantibodies. The two patients with sclera-specific autoantibodies presented simultaneous reactivity in IIF and in Western blot, suggesting that the same autoantibody was detected in the two assays. This possibility needs to be tested by proceeding to an analysis of the IIF aspect of affinity-purified antibodies from the $15 \mathrm{kDa}$ and $45 \mathrm{kDa}$ bands.

The distribution of age and gender was characterized by a high prevalence of individuals above 50 years of age (60\%) and a strong prevalence of women (88\%), which is compatible with information available from the literature ${ }^{(11)}$. The frequency of bilateral scleritis (24\%) was less than that reported ${ }^{(8)}$. These authors found bilateral scleral involvement 
in about $50 \%$ of their cases. The frequency of corneal involvement in the present study (28\%) was roughly equivalent to that observed by others ${ }^{(21)}$.

Although diffuse anterior scleritis is the most prevalent form reported in the literature ${ }^{(11)}$, we found a higher frequency of nodular anterior scleritis (52\%).

Idiopathic scleritis, without association with systemic disease, was the most frequent presentation (88\%), which is comparable to the findings of Watson et al. ${ }^{(2)}$. However, it is known that several rheumatic systemic diseases may be associated with scleritis. The involvement of the eye, and particularly of the sclera, during the course of systemic rheumatic diseases is a consensus in the literature. In the present series, this was represented by systemic lupus erythematosus and rheumatoid arthritis in $12 \%$ of patients ${ }^{(11)}$. The association with this type of systemic disease is an indication of the role of the immune system in the pathophysiology of scleritis, but in our series this association was weak with most cases not presenting an underlying disease.

Previous occurrence of eye surgery or eye inflammatory conditions, such as occurred with a few patients in our study (8\%), could represent an initial stimulus for the formation of antibodies against sclera-specific antigens ${ }^{(22)}$. Surgicallyinduced exposure of eye antigens under an inflammatory environment may trigger the sensitization of both humoral and cellular immunity ${ }^{(23)}$. The reduction of reports of this type of scleritis in the era of phacoemulsification, as opposed to extracapsular extractions, is good evidence of this. The observation that scleritis may occur even several years after the surgery suggests that immune disorder triggered by the original autoimmunization stimulus may take years to become clinically manifest ${ }^{(24)}$.

The association between autoantibodies and scleritis is poorly documented in the literature. In the present report it is noteworthy that one of the patients with scleritis presented high rates of antinuclear factor without any other noticeable cause, such as systemic lupus erythematosus, autoimmune thyroiditis, infections, chronic use of medicines, or any other systemic disease. According to Zierhut et al. ${ }^{(25)}$, approximately $28 \%$ of patients with scleritis are ANA-positive. The presence of anticardiolipin antibodies, in patients with scleritis was previously described ${ }^{(6)}$ and was observed in two patients of this study, although in very low titer. Although the anti-phospholipid antibodies are markers of thrombogenic syndromes and are frequently found in systemic lupus erythematosus ${ }^{(26,27)}$, they may also be detected in low titer and transiently in several inflammatory conditions and idiopathic scleritis could well represent one of those. Some authors argue that the presence of low titer anticardiolipin antibodies is a non-specific expression of auto-immunity with multi-systemic involvement and may also be found in idiopathic scleritis ${ }^{(11)}$.

Antiperinuclear factor (APF) was positive in two of our patients. This is an interesting finding since we could find no other reports of this occurrence. In addition, none of these two patients presented any evidence of systemic rheumatic disease. Curiously, one the patients presented both APF and ANA. APF represents one of the diagnostic tools for detection of autoantibodies to citrullinated peptides, which have been shown to be highly specific for rheumatoid arthritis ${ }^{(28)}$. Currently, this class of autoantibodies is considered the main diagnostic marker for rheumatoid arthritis. They are detected early in the course of the disease, even before clinical signs and symptoms, as observed in a study performed with blood donors who developed rheumatoid arthritis but who already presented these antibodies several years before the appearance of the disease. In addition, some authors show evidence that high titer of autoantibodies to citrullinated peptides may also suggest a prognostic factor ${ }^{(29-30)}$. The significance of APF in our series of patients with idiopathic scleritis is not clear at the present time. However, one can not rule out the possibility that these patients may develop rheumatoid arthritis within the next years.

With respect to traditional autoantibodies, their investigation has only been recommended for scleritis patients with clinical evidence of systemic diseases ${ }^{(8)}$. In face of the present results, we recommend, however, that each patient with idiopathic scleritis should also have a standard autoantibody screening, since a positive result may identify a subset of these patients who will eventually develop systemic manifestations.

Organ-specific autoantibodies in ophthalmology have been demonstrated before. The presence of specific autoantibodies against cornea, iris, crystalline, and some proteins of the posterior segment as antigen- $S$ and rodopsin have been reported, specially in the context of idiopathic uveitis $^{(31,32)}$. Our group has demonstrated the presence of specific antibodies against uveal extract in patients with non-HLA-B27 associated idiopathic uveitis ${ }^{(32)}$. However, the literature does not report on autoantibodies in idiopathic scleritis. Therefore the current demonstration of autoantibodies directed against two polypeptides (15 kDa e $40 \mathrm{kDa}$ ) present in human sclera extract is relevant and raises the possibility of an organ-specific autoimmune process. It should be mentioned that this reactivity in western blot corresponded to an intense fluorescence staining in scleral tissue, what brings credibility to both findings. 
Similar to the inflammatory infiltrate observed in rheumatoid arthritis, scleritis is represented predominantly by a cellular infiltrate represented by macrophages and CD4 T-lymphocytes, which usually are not observed within the normal sclera ${ }^{(24)}$. The present study showed for the first time the participation of humoral immunity in this

\section{REFERENCES}

1. Hamideh F, Prete PE: Ophthalmologic manifestations of rheumatic diseases. Semin Arthritis Rheum 30(4): 217-41, 2001.

2. Watson PG, Hayreh SS: Scleritis and episcleritis. Br J Ophthalmol 60:163-91, 1796.

3. Pavésio CE, Méier FM: Systemic disorders associated with episcleritis and scleritis. Curr Opin Ophthamol 12(6): 471-8, 2001.

4. di Girolamo N, Visvanathan K, Lloyd A, Wakefield D: Expression of TNF-alpha by human plasma cells in chronic inflammation. J Leukoc Biol 61(6): 667-78, 1997.

5. Dong X, Wang J, Kabir FN, et al.: Autoantibodies to DEK oncoprotein in human inflammatory disease. Arthritis and rheumatism 43(1): 85-93, 2000.

6. Miserocchi E, Baltatzis S, Foster CS: Ocular features associated with anticardiolipin antibodies: a descriptive study. Am J Ophthalmol 131(4): 451-6, 2001.

7. John SL, Morgan K, Tullo AB, Holt PJ: Corneal autoimmunity in patients with peripheral ulcerative keratitis in association with rheumatoid arthritis and Wegener's granulomatosis. Eye 6(6): 630-6, 1992.

8. Akpek EK, Thorne JE, Qazi FA, Do DV, Jabs DA: Evaluation of patients with scleritis for systemic disease. Ophthalmol 111(3): 501-6, 2004.

9. Akpek EK, Liu SH, Gottsch JD: Induction of experimental autoimmune keratitis by adoptive transfer of human corneal antigen specific $\mathrm{T}$ cell line. Invest Ophthalmol Vis Sci 4l(13): 4182-8, 2000.

10. Young RD, Powell J, Watson PG: Ultrastructural changes in scleral proteoglycans precede destruction of the collagen fibril matrix in necrotizing scleritis. Histopathology 12(1): 75-84, 1988.

11. Watson PG, Hazleman B, Pavésio C, Green WR: The sclera and systemic disorders - second edition. London: BH; 2004.

12. Oréfice F, Belfort Jr. R: Uveítes. São Paulo: Roca; 1987.

13. Sainz de la Maza M, Foster CS, Jabbur NS: Scleritis associated uveitis. Ophthalmol 104(1): 58-63, 1997.

14. Friou GJ, Haven W: Clinical application of a test for lupus globulin-nucleohistone interaction using fluorescent antibody. Yale J Biol 31:40-47, 1958

15. Singer JM, Plotz CM: The latex fixation test. I. Application to the serologic diagnosis of rheumathoid arthritis. Am J Med 21:888-892, 1956

16. Harris EN, Gharavi A, Platel SP, Hughes GRV: Evaluation of the anticardiolipin antibody test: report of an international workshop held April 1986. Clin Exp Immunol 68: 215-222, 1987.

17. Aarden LA, De Groot ER, Feltkamp TEW: Immunology of DNA III Crithidia luciliae: a simple substrate for determination of anti- dsDNA with the immunofluorescence technique. Ann NY Acad Sci 254: 505-15, 1975. process. This is an interesting finding and further studies in a larger number of patients may shed more light into this immune mechanism, which may also have therapeutic implications.

\section{Conflits of interest: nothing to disclose.}

18. Yamagata H, Harley JB, Reichlin M: Molecular properties of the Ro/ SS-A antigen and enzyme linked immunoabsorbent assay for quantification of antibody. J Clin Invest 47: 625-33, 1984.

19. Rao JK, Weinberger M, Oddone EZ, Allen NB, Landsman P, Feussner JR: The role of antineuntrophil cytoplasmic antibody (c-ANCA) testing in the diagnosis of Wegener granulomatosis. A literature review and meta-analysis. Ann Intern Med 123(12): 925-32, 1995.

20. Hoet, RMA: Detection of antiperinuclear factor and antikeratin antibodies. Manual of Biological Markers of Disease; New York: CSH, 1993.

21. Sainz de la Maza M, Foster CS, Jabbur NS, Baltatzis S: Ocular characteristics and disease associations in scleritis-associated peripheral keratopathy. Arch Ophthalmol 120(1): 15-9, 2002.

22. Díaz-Valle D, Benítez del Castilho JM, Castillo A, Sayagués $\mathrm{O}$, Bañares A, García-Sánchez J: Immunologic and clinical evaluation of postsurgical necrotizing sclerocorneal ulceration. Cornea 17(4): 371-5, 1998.

23. Pepose JS, Holland GN, Wilkhemus KR: Ocular Infection \& Immunity. St. Louis: Mosby, 1996.

24. Watson PG, Young RD: Scleral structure, organisation and disease. A review. Exp Eye Res 78(3): 609-23, 2004.

25. Zierhut M, Denk PO, Klein R, Berg PA, Erb C, Thiel HJ: Autoantibody pattern in scleritis and episcleritis. Ophthalmologe 94(2): 157-60, 1997.

26. Prado FC, Ramos JA, Valle JR: Atualização terapêutica. São Paulo: Artes Médicas; 2001.

27. Love PE, Santoro SA: Antiphospholipid antibodies: anticardiolipin and the lupus anticoagulant in systemic lupus erythematosus (SLE) and in non-SLE disorders: prevalence and significance. Ann Intern Med 112: 682, 1990.

28. Andrade LEC: O sistema de auto-anticorpos contra peptídeos citrulinados na artrite reumatóide. Sinopse de Reumatologia 6(1): 3-7, 2004

29. Vallbracht I, Rieber J: Diagnostic and clinical value of anti-cyclic citrullinad peptide antibodies compared with rheumatoid factor in rheumatoid arthritis. Ann. Rheum Dis 63:1079-84, 2004.

30. Nielen MM, van Schaardenburg D: Specific autoantibodies precede the symptoms of rheumatoid arthritis: a study of serial measurements in blood donors. Arthritis Rheum 50(2): 380-6, 2004.

31. Pfister C, Dorey C, Vadot E, Mirshahi M, Deterre P, Chabre M, Faure JP: Identification of the so-called 48 K protein that interacts with illuminated rhodopsin in retinal rods, and the retinal $S$ antigen, inductor of experimental autoimmune uveoretinitis. C R Acad Sci III 299(8):261-5, 1984

32. Trevisani VFM, Mattos KTF, Esteves RF, Olialves SMR, Andrade LEC: Autoantibodies specificity in acute anterior uveitis according to the presence of the HLA-B27 allele. Ocul Immunol Inflamm 9(4): 231-42, 2001. 